\title{
SOEP
}

SOEPpapers

SOEPpapers
on Multidisciplinary Panel Data Research
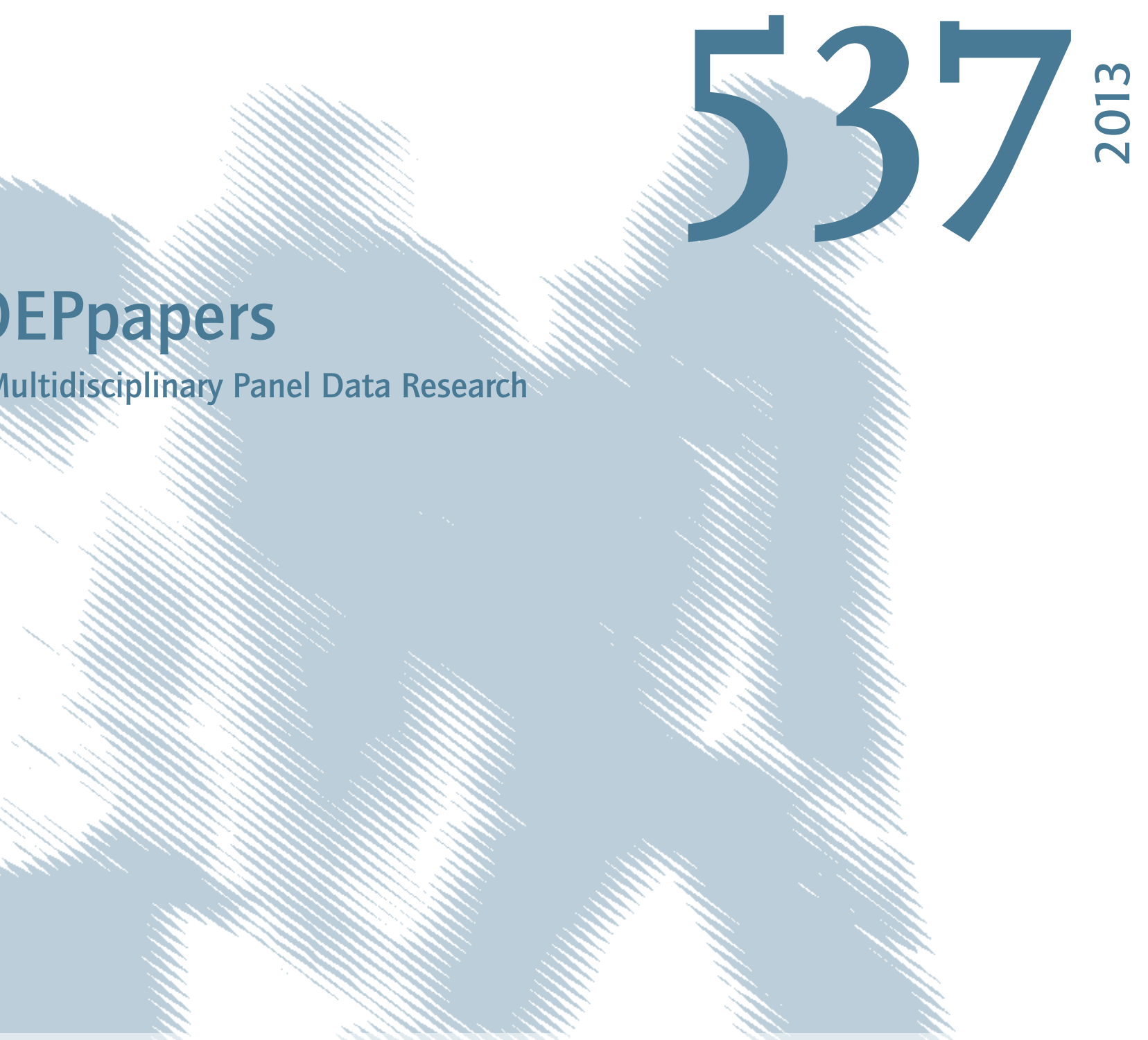

\section{The Impact on Earnings When Entering Self-Employment - Evidence for Germany}




\section{SOEPpapers on Multidisciplinary Panel Data Research}

at DIW Berlin

This series presents research findings based either directly on data from the German SocioEconomic Panel Study (SOEP) or using SOEP data as part of an internationally comparable data set (e.g. CNEF, ECHP, LIS, LWS, CHER/PACO). SOEP is a truly multidisciplinary household panel study covering a wide range of social and behavioral sciences: economics, sociology, psychology, survey methodology, econometrics and applied statistics, educational science, political science, public health, behavioral genetics, demography, geography, and sport science.

The decision to publish a submission in SOEPpapers is made by a board of editors chosen by the DIW Berlin to represent the wide range of disciplines covered by SOEP. There is no external referee process and papers are either accepted or rejected without revision. Papers appear in this series as works in progress and may also appear elsewhere. They often represent preliminary studies and are circulated to encourage discussion. Citation of such a paper should account for its provisional character. A revised version may be requested from the author directly.

Any opinions expressed in this series are those of the author(s) and not those of DIW Berlin. Research disseminated by DIW Berlin may include views on public policy issues, but the institute itself takes no institutional policy positions.

The SOEPpapers are available at

http://www.diw.de/soeppapers

\section{Editors:}

Jürgen Schupp (Sociology, Vice Dean DIW Graduate Center)

Gert G. Wagner (Social Sciences)

Conchita D'Ambrosio (Public Economics)

Denis Gerstorf (Psychology, DIW Research Director)

Elke Holst (Gender Studies, DIW Research Director)

Frauke Kreuter (Survey Methodology, DIW Research Professor)

Martin Kroh (Political Science and Survey Methodology)

Frieder R. Lang (Psychology, DIW Research Professor)

Henning Lohmann (Sociology, DIW Research Professor)

Jörg-Peter Schräpler (Survey Methodology, DIW Research Professor)

Thomas Siedler (Empirical Economics)

C. Katharina Spieß (Empirical Economics and Educational Science)

ISSN: 1864-6689 (online)

German Socio-Economic Panel Study (SOEP)

DIW Berlin

Mohrenstrasse 58

10117 Berlin, Germany

Contact: Uta Rahmann | soeppapers@diw.de 


\title{
The Impact on Earnings When Entering Self-Employment - Evidence for Germany
}

January 2013

Author: Johannes MARTIN, RWTH Aachen University, Chair of Human Resource Management and Personnel Economics, Templergraben 64, 52056 Aachen, E-Mail: johannes.martin@rwth-aachen.de, Tel: ++49 2418093369

\begin{abstract}
Using data of the German Socio-Economic Panel (GSOEP) earnings differentials between self-employed and wage-employed workers in the German labor market are explored. Previous research based on US data reports lower incomes for entrepreneurs. In contrast to that, the findings of this contribution suggest the opposite for German entrepreneurs. They have considerably higher earnings than wage-employed workers. Furthermore, there is a significant and positive effect on earnings when entering self-employment. This holds true when it is also taken into account that workers usually report a smaller firm size and work longer after beginning an entrepreneurial occupation.
\end{abstract}

JEL-Codes: L26, J31, J32

Keywords: Self-employment, Human Capital, Earnings, GSOEP, Entrepreneurship 


\section{Introduction}

One of the most important issues regarding the decision on an occupation is the expected monetary compensation. It is also relevant for one's decision to engage in self-employment ${ }^{1}$. Prior research show that the probability of becoming self-employed is influenced by the magnitude of the expected earnings difference between an occupation in wage-employment and in self-employment (Hammarstedt, 2009; Johansson, 2000). Though, literature provides empirical evidence that US workers abstain from at least some part of their income gained in wageemployment when they move into self-employment (Hamilton, 2000). There is however a lack of research for the German labor market. Older, rather general descriptive data of the OECD suggest that the situation in Germany could be different as median earnings of entrepreneurs are higher than those of employees (Oecd, 1992). Hence, the aim of this paper is to investigate thoroughly the income situation for self-employed people in Germany in comparison to wages of employees.

There are several difficulties that arise when investigating earnings differences between selfemployed and wage-employed people (Parker, 2004). First, the entrance in self-employment should not be random, but depends on observable and unobservable factors see Bergmann and Sternberg (2007) for an overview of possible determinants of becoming self-employed). Caliendo et al. (2011) emphasize the importance of personality traits such as openness for experience and extraversion regarding the decision to become an entrepreneur. Hence, biased results are likely to occur if this issue of sample selection is not taken into account. Second, previous studies revealed that the rent of some determinants of earnings (for example school-

\footnotetext{
${ }^{1}$ In this contribution „self-employment“ and „,being entrepreneur“ are used as synonyms. Self-employed persons are thereby understood as people who run their own business. For a discussion of differences and similarities between both constructs see Parker (2004), pp. 5-8.
} 
ing) is different in self-employment, which ought to be considered as well. Third, the measurement of "earnings" in the context of self-employment is connected with several problems which possibly hinder the comparability of wage-employed and self-employed earnings. Fourth, the group of entrepreneurs is heterogeneous which could lead to different earnings effects for different subgroups.

As a result, previous studies often suffer from a methodological approach that handles these difficulties in an insufficient way. In addition, the existing research on this topic is rather scarce (Van Praag and Versloot, 2008). However, there are some contributions that analyze earnings differentials profoundly. In a seminal paper, Hamilton (2000) examines the observed positive earnings differential between wage and self-employment in the US, based on data of non-agricultural male workers from the years 1983 until 1986. He conducts separate wage regressions for both self-employed workers and wage-employed workers. Hence, he does not explore a certain "switching rent" when moving from one to another sector, but he obtains rather indirect findings: He finds that self-employed workers have both lower initial earnings and lower income increases over time than wage-employed workers. The results are stable for different measures of self-employment earnings and across industries. However, it is not controlled for unobserved individual heterogeneity within his analysis. Kawaguchi (2002) replicates Hamilton's results with the 1985-1998 data of the US National Longitudinal Survey of Youth (NLSY), restricted to white male workers. He finds that self-employed workers achieve lower returns according to their work experience and tenure and, as a result, earn considerably less which holds true for experienced individuals in particular. However, these are results of a simple OLS estimation. When accounting for unobserved heterogeneity by using a fixed-effects estimator, the differential shrinks considerably. These findings indicate that selfemployment earnings are heavily influenced by selection effects. 
Van Praag et al. (2009) put their main focus on different returns to education in the wage- and self-employment sector. Using the NLSY data from 1979 until 2000, they find that entrepreneurs obtain higher returns on their (formal) education. Moreover, their results indicate that self-employed workers have more personal control over their work environment which influences the returns to education. However, when accounting for unobserved characteristics and possible selection biases, the earnings effect of self-employment becomes insignificant. There are several other contributions that confirm higher returns to education for self-employed workers, see for example Williams (2003) for the German labor market. Block et al. (2009) find that foreigners denote higher earnings in self-employment than in wage-employment. Furthermore, their results indicate that foreign workers compared to Germans have higher earnings increases due to the entry into self-employment. However, for the best of knowledge, there is no paper which investigates income differences between self-employed and wageemployed workers with German data.

Therefore, this contribution analyzes possible earnings differentials by using data of the German Socio-Economic Panel (GSOEP) from 1984 to 2008. In order to control for a possible sample selection bias, a fixed-effects estimator is conducted. Different ways of earnings determination are methodologically allowed by interacting the wage-employment vs. selfemployment dummy variable with other influencing factors such as individual and jobspecific characteristics on income. Possible heterogeneity within the self-employment group with respect to earnings effects is investigated by differentiating between short-term and longterm earnings effects of the transition into self-employment. In addition, different subgroups with respect to sex or occupation are investigated more thoroughly.

The remainder of this paper is structured as follows: In section 2, theoretical considerations and hypotheses will be elaborated. Section 3 illustrates the methodology and describes the 
data. Section 4 contains the empirical results. Section 5 discusses the findings and gives some concluding remarks.

\section{Theoretical considerations}

Workers should move to self-employment if they expect a higher utility as in their present occupation (or in unemployment). In the following, it is assumed that the utility of an occupation depends on two different forms of influencing factors: First, there are monetary rewards that wage-employed workers receive in terms of wages or salaries (in the broadest sense, i.e. including non-pecuniary benefits like a company car or pecuniary benefits such as pension stakes). For self-employed workers, monetary rewards are funds they can extract out of their business for personal purposes. Second, there could also be some non-monetary rewards, for example enjoying the work or the possibility to align private life with occupational life through flexible working time. A worker will choose the occupation that is connected with the highest utility. The decision depends on individual preferences.

The literature offers arguments for both higher and lower earnings of self-employed compared to wage-employed people. First, entrepreneurs could face a higher autonomy in their job because they are not embedded in a firm hierarchy that is characterized by vertical instructions and control (Hamilton, 2000). This is true for both work contents (in particular the purpose of the business) and the order in which they are executed. Benz and Frey (2008) are able to prove empirically that self-employed workers have a higher procedural utility than wageemployed workers. Hence, they are more satisfied with the way their work output is achieved. The authors ascribe this finding to a higher degree of self-determination and freedom that entrepreneurs experience during work. Block and Köllinger (2009) find that workers who 
become self-employed care for money, but also strive to achieve independence and to live their creativity. In the view of Hamilton (2000), this benefit from non-monetary sources is sufficient for workers to accept a lower income when switching to self-employment.

Astebro and Thompson (2009) also refer to the non-monetary rewards of self-employment: Entrepreneurs have a special "taste for variety" making them strive for as much variety in their occupational life as possible. However, firms are often characterized by a more or less high division of labor which leads to specialization on single jobs. Hence, the tasks on jobs within a firm hierarchy are rather specific. In contrast, tasks of self-employed workers are much more widespread. Lazear (2005) argues that entrepreneurs have to be a "jack-of-alltrades" which indicates that they need talents in many fields, e.g. human resource management, sales or finance management. Within his contribution, he is able to provide evidence that entrepreneurs possess a broad talent set while employees have more specialized skills. Based on this "jack-of-all-trades"-argument, Astebro and Thompson (2009) argue that if there is a free occupational choice, workers with a preference for a job providing a great variety are more likely to move into self-employment. Assuming that this variety is a substitute for monetary rewards, this argument would also permit a lower income in self-employment.

On the other hand, there are also aspects in favor of higher earnings in self-employment. Douhan and Van Praag (2009) refer to the point that entrepreneurs may make use of their own skills and knowledge more effectively than in wage-employment. As their own boss, they may adjust the intra-firm processes so that the returns on their human capital will be maximized. In contrast, adjustments of work processes to the skills of single employees are only possible up to a certain degree due to the constraints by the organizational structure of the firm. Consequently, it could be said that the human capital in self-employment is used more efficiently than in wage-employment, which fosters a higher income for entrepreneurs. 
According to Jensen and Shore (2008), earnings of self-employed people are more volatile. Because of that, income risks for entrepreneurs are obviously higher than for employees. Under the common assumption of risk aversion, this risk has to be compensated so that the worker is willing to move into self-employment. In this case, a positive income differential between self-employment and wage-employment can be regarded as a risk premium.

The ideas of human capital and agency models could also be relevant. They postulate different earnings profiles in both sectors (Lazear, 1981; Lazear and Moore, 1984). Investments in the human capital of entrepreneurs have to be paid totally by themselves. Particularly at the beginning of an entrepreneurial occupation, it seems likely that financial funds have to be invested, for instance in knowledge about the industry or in learning of accounting rules. Consequently, the income at the beginning of a job is lower when being self-employed. However, returns to these investments over time can be absorbed completely by the entrepreneur, while investment-models assume that for individuals in wage-employment both investment costs and returns are shared between employer and employee (Becker, 1962). In contrast, agency models predict an opposite trend: Whereas wage-employment occupations ask for incentives to prevent shirking behavior by the employees, this problem does not exist in selfemployment occupations. Such incentives are often set by increasing wage profiles over time which leads to lower incomes at the beginning and higher incomes at the end of the occupational life. According to these two models, it depends on the time within the occupational career if an entrepreneur earns more or less than an employee. However, these arguments are only relevant for analyses of income differences between wage-employed and self-employed, not for analyses of earnings effects connected with switches to or from an entrepreneurial occupation. 
In conclusion, it is not possible to make a straightforward theoretical prediction. Workers could earn more in self-employment by using their skills and knowledge more efficiently. But it is also possible that they receive lower monetary rewards because the non-monetary benefits are substantial. Finally, both effects could also occur together leading to the question which of the two effects is stronger.

\section{Data, Variables and Methodology}

\subsection{Dataset}

The analysis in this contribution is based on the GSOEP, which is a representative dataset of German inhabitants. ${ }^{2}$ Individuals are asked on a yearly base about several areas of life including general attitudes and their employment relationship. The panel structure allows for longitudinal analyzes of individual careers and, in particular, for the observation of individual transitions from wage-employment into self-employment (and vice versa) from 1984 to 2008. The dataset is restricted to people who are employed full-time in the private or the public sector. Apprentices and trainees are not included. Furthermore, the agricultural sector is excluded as commonly accepted for studies with respect to this topic. Altogether, the dataset with an unbalanced panel structure consists of 135,330 year-observations of 20,793 people, including 10,381 year-observations (i.e. 7.7 percent) of self-employed workers.

\footnotetext{
${ }^{2}$ The data are provided by the German Institute of Economic Research (DIW, Berlin). For a detailed description see http://www.diw.de/en/soep.
} 


\subsection{Variables}

The job status is defined by a dummy variable: For wage-employed people the variable adopts “0”, for self-employed people "1". Self-employment is understood in a relatively broad fashion as it includes all workers who run their own business. Hence, this group includes nascent entrepreneurs and also people in liberal professions like pharmacists or lawyers, for instance. Table 1 provides an overview over the dataset structure. Self-employed workers are seldomly female, more frequently German and more often married. On average, they are older than wage-employed workers and have received more formal schooling. More frequently, they work in the occupation they are trained for. The size of the enterprise self-employed workers are working in is considerably smaller. Their weekly working time is much longer. They work more often in the trade and finance industries and less frequent in the manufacturing sector. For an overview over the definition and the operationalization of all variables uses in this contribution, see the Appendix.

\section{---> Table 1 about here <---}

Entrepreneurship literature hints on several possible problems connected with the measurement of self-employment earnings (Parker, 2004). In general, it is assumed:

$$
\text { Net profit } \equiv \text { Revenue }- \text { Costs } \equiv \text { Draw }+ \text { Retained earnings }
$$

The net profit of a firm is thereby the difference between the revenue and all costs including taxes. Entrepreneurs can dispose of this profit: Either they extract it for their personal purposes, or they leave it within the firm ( = invest it). Comparing the earnings in wage-employment and self-employment, it seems reasonable to focus on the financial funds the entrepreneur uses for his own purposes. In both cases, the benefitted person is able to dispose directly over 
the money. The GSOEP questionnaire asks for income from self-employment which entrepreneurs are supposed to understand in this sense.

However, there are some hints in the literature that self-employment earnings are over- or underestimated. On the one hand, self-employment earnings may be underreported as the survey participants mistrust the independence of the interviewer from tax agencies. On the other hand, the income of entrepreneurs could also be overreported if they are a mixture of labor and capital income. Furthermore, German employers obligatorily discharge some parts of the gross wage to social insurance systems as for example pension insurance or unemployment insurance. About the same amount is paid by the employer additionally, whereat this money is normally not considered by the employees as part of their wage. For entrepreneurs, there are no legal obligations to pay into such systems. Hence, their income should be higher. To be fair, the self-employed could also report earnings which they pay to a private illness insurance afterwards. Consequently, these parts of income would not be disposable in the above defined sense. However, at least some part of the investments in their own firms (thus lowering the amount to which funds can be extracted by the entrepreneur for consumption in the present) can also be seen as financial precaution for their future.

In conclusion, it cannot be stated that self-employment earnings are systematically biased towards one direction. However, the potentially restricted validity of earnings statements especially of self-employed workers should be taken into account when discussing the results.

\subsection{Methodology}

For both wage-employed and self-employed people it is assumed that the determination of their income follows the logic of the Mincerian earnings regression. Thus, logarithmized 
gross earnings act as dependent variable. As workers are supposed to calculate rather with the whole monthly sum they get from a job than with a virtual hourly rate, the monthly income is chosen as the dependent variable in all of the regressions. The dataset contains information from a time span of 24 years, thus the earnings are inflated by the consumer price index to the prices of 2008.

As a reference, a simple OLS model is conducted in order to examine average differences. However, the entrance into self-employment should not be random, but dependent on many factors such as individual or job-specific characteristics. Hence, a model which does not account for these characteristics would lead to results biased by sample selection. Previous contributions which investigated cross-sectional data used a two-stage Heckman correction to handle this problem. It corrects the Mincerian equation for differences with respect to the probability of becoming self-employed. The disadvantage of these studies is that one cannot control for unobserved heterogeneity that is likely to affect earnings. However, the transfer of the Heckman correction on longitudinal data is not trivial. In this paper, a simple fixed-effects estimator is applied. The advantage of this method is that unobserved individual heterogeneity, like motivation or personal traits possibly affecting earnings, can be filtered. Furthermore, the individual fixed-effects should capture selectivity due to "permanent disposition, inclination and aptness for entrepreneurial activity" (Van Praag et al., 2009). Only non-permanent selectivity, that is, special circumstances or events which foster the entrance into selfemployment, cannot be captured by the fixed-effects estimator.

Previous research showed that the return to schooling for self-employed people is different from that of wage-employed workers (see for example Williams (2003) for the German labor market). We can assume that there should also be differences with respect to other determinants of individual earnings. Hamilton (2000) and Williams (2003) handled this problem by 
estimating two different models for wage-employed and self-employed workers. Though, this approach makes it impossible to estimate the direct earnings effect of switching from the wage sector to the self-employed sector (and vice versa). Hartog et al. (2010) extended their model by interactions of all earnings determinants with the sector dummy "self-employed". In consequence, the coefficients of schooling, age and other factors measure income effects of wage-employed workers. Coefficients of interaction effects reveal possible differences between the two sectors with respect to income determinants. The dummy "self-employed yes/no" (below: $S E$ ) indicates the earnings change when switching from wage-employment (below: $W E$ ) to self-employment, accounting for (permanent) selectivity and different ways of earnings determination in both sectors. This approach is also used in this contribution. The whole model can be described by

$$
\log (\text { Monthly earnings })=\propto+S E \cdot \beta+A^{\prime} \gamma+S E \cdot A^{\prime} \delta+\varepsilon
$$

whereas $\alpha$ stands for the intercept and $S E$ for a dummy that adopts " 0 " for workers in the wage sector and " 1 " for those in self-employment. $A$ is a vector of several characteristics that potentially exert influence on earnings: socio-demographics like sex, the nationality or the marital status, variables that act as proxies for the worker's human capital (years of schooling for formal education, age and a dummy for working in the occupation someone was trained for to capture general occupational skills and tenure for firm-specific human capital) and finally firm-specific factors like industry or firm size. Control variables for the region and the observation year are also included. $S E \cdot A$ is a vector of interactions between these influence factors and SE (except for the region and the observation year). $\varepsilon$ is an error term. $\beta$ indicates the earnings effect of being (OLS estimations) or becoming (fixed-effects estimations) selfemployed. $\gamma$ and $\delta$ are coefficient vectors of earnings effects of the other determinants and their interactions with $S E$. 
In consequence, the resulting income effect of self-employment (i.e. the coefficient of $S E$ ) is not independent of the interaction effects. Hence, the coefficient can only be interpreted directly when all factors interacted with $S E$ adopt the value of zero. In the case of dummy and categorical variables, one can choose a certain reference category. With respect to continuous variables as for example the individual age, the value zero is not meaningful in most cases. Therefore, all values of continuous variables are demeaned by the mean of the whole sample. By doing so, the coefficient of $S E$ now indicates the earnings effect of becoming selfemployed for a person within the chosen reference categories respectively with average values for the continuous variables.

Conventional regression models capture observable heterogeneity, for example with respect to age or sex, simply by integrating these variables on the right hand side of the regression equation. However, individual unobservable characteristics cannot be captured as easily due to the lack of data. Instead, a fixed-effects estimator uses the within transformation. A simple model with one explanatory variable shall adopt the following form (Wooldridge, 2006):

$$
y_{i t}=\alpha_{i}+\beta_{1} \cdot x_{i t}+u_{i t}
$$

whereas $i$ stands for the person and $t$ for the time of observation. Averaging $\mathrm{y}$ and $\mathrm{x}$ over time leads to

$$
\bar{y}_{i}=\alpha_{i}+\beta_{1} \cdot \bar{x}_{i}+\bar{u}_{i}
$$

By subtracting (2) from (1), we get the equation

$$
\left(y_{i t}-\bar{y}_{i}\right)=\beta_{1} \cdot\left(x_{i t}-\bar{x}_{i}\right)+\left(u_{i t}-\bar{u}_{i}\right) .
$$

With this approach, the time-constant individual effects $\left(=\alpha_{i}\right)$ drops out of the equation and a simple pooled OLS estimator can be used. In the context of this study, the coefficient of $S E$ is 
only influenced by the observations of those workers who are at least one period in wageemployment and also at least one period in self-employment (otherwise, $\left(x_{i t}-\bar{x}_{i}\right)$ equals always zero). In consequence, earnings of "long-time" entrepreneurs become irrelevant. Furthermore, movements to or out of self-employment have the equal impact on the effect. Observations conducted right after the transition do have the same value as later observations. That way, the coefficient of the fixed-effects estimation indicates the average income difference between an occupation in wage-employment and self-employment, controlled for constant, individual, and unobserved heterogeneity.

In a second step, we analyze the short-term effect of switching from one status to the other. For this purpose, a first-differences estimation will be applied. This approach also eliminates the individual effects, but in a different way (Cameron and Trivedi, 2009):

$$
\left(y_{i t}-y_{i, t-1}\right)=\beta_{1} \cdot\left(x_{i t}-x_{i, t-1}\right)+\left(u_{i t}-u_{i, t-1}\right)
$$

In each period, the difference between the actual period and the preceding period will be computed. The coefficient of $S E$ depends only on the observations right before and after a switch. Hence, it indicates the short-term effect.

\section{Empirical Results}

In this chapter, empirical results with respect to earnings differences between self-employed and wage-employed workers are illustrated. To give a first overview, some descriptive results are shown in chapter 4.1 . 


\subsection{Descriptive Results}

Table 2 delivers a first glance on differences with respect to earnings. It describes the monetary rewards of all entrepreneurs and employees. Three aspects are evident: First, selfemployed workers earn, on average, significantly more than wage-employed workers. This holds true when looking at monthly as well as hourly earnings ${ }^{3}$. Second, income differences are smaller on an hourly base. This indicates that self-employed workers receive higher monthly rewards, but work more hours, too. Third, the variance of entrepreneur rewards is higher than that of employee's earnings. In addition, the differences between median payments are smaller than those between mean payments. That is, the self-employment sector is much more heterogeneous than the wage-employment sector with respect to earnings.

\section{---> Table 2 about here <---}

Figure 2 and 3 show the earnings trend over time. Figure 2 describes monthly earnings, Figure 3 presents hourly earnings. Both diagrams confirm the findings of Table 2 as selfemployed workers have considerably higher mean earnings while the difference is considerably smaller when looking at the median digits. On an hourly basis, the difference is not even recognizable. There is no time trend as the differential between self-employed and wageemployed income is stable over the whole time span.

\section{---> Figure 1 about here <--- \\ ---> Figure 2 about here <---}

In Table 3, relative increases in income from the period right before until the period directly after a switch to or from self-employment are shown. Doing this, the sample size decreases in

\footnotetext{
${ }^{3}$ Hourly earnings are computed as follows: Hourly Earnings $=($ Monthly Earnings $/($ Weekly Earnings $* 52 / 12))$
} 
the amount of 22 percent due to the fact that the GSOEP is an unbalanced panel. As a reference, income of workers without a switch are also tabulated. There are some interesting details: First, one can see that workers who move from the wage sector into the entrepreneurial sector have on average increasing earnings. The median rise of monthly income is 8.7 percent. In contrast, the monthly incomes of workers who move from self-employment to wage-employment decreases by 2.1 percent. Overall, 59.1 percent of those who enter selfemployment "win" after the switch, that is they receive higher monthly earnings. In contrast to that, 57.4 percent denote lower monetary rewards when they switch from self-employment to wage-employment.

However, the results are quite different when looking at the hourly earnings. Those who switch into self-employment have a median decrease of their hourly income of 0.6 percent, while workers who move from self-employment to wage-employment report an increase in income of 0.5 percent. Hence, a switch to self-employment appears to be connected with a higher income but also comes along with more working hours. Finally, we can see that earnings differences over two years are considerably higher when workers feature a change in their job status which allows for the conclusion that entry into self-employment also influences the income of workers.

---> Table 3 about here <---

Earnings depend not only on the employment status, but also on other factors like individual or job-specific characteristics. Furthermore, we can assume that different determinants have a different influence on earnings of self-employed and wage-employed people. Finally, selection effects could influence the decision to become an entrepreneur. These are arguments that are in favor of the conclusion that the descriptive results are only first indications of the true 
effect of self-employment on income. Hence, several multivariate analyzes are conducted in the following.

\subsection{Multivariate Results}

Results of regressions on monthly gross income are shown in Table 4. In model (1), an OLS estimation without interaction variables is conducted. This approach assumes that the different determinants have the same influence on earnings in both wage-employment and selfemployment. Under this assumption, entrepreneurs earn $18.7^{4}$ percent more than employees. In (2), a fixed-effects estimator is used in order to capture unobservable heterogeneity that could also influence incomes. The earnings difference of 10.8 percent is considerably smaller which indicates that unobservable characteristics are highly relevant.

In model (3), all factors are interacted with the self-employment dummy. The main effects are rather stable. However, the interaction effects are partly significant, too. This indicates that many determinants, indeed, act differently in the respective sectors. Especially foreigners benefit from an entrepreneurial occupation, while additional working time is connected with a lower earnings premium when the worker is self-employed. Overall, a self-employed worker receives earnings that are 13.0 percent higher, compared to an occupation with the same characteristics in wage-employment.

Using this approach, we assume that the switch from one occupation to the other has no impact on other attributes. This assumption is not problematic when looking at sociodemographic characteristics like the personal age or the marital status. In addition, Lohmann

\footnotetext{
${ }^{4}$ As the dependent variable is logarithmized, the coefficient has to be transformed by the exponential function to get the exact effect.
} 
and Luber (2004) show that German workers often move into self-employment within the same industry as they were employed before. However, most of the entries into selfemployment should be connected with a switch into a lower firm size class. Therefore, model (4) does not control for firm size. Yet, the earnings difference indicated by the coefficient of the self-employment dummy already contains the effect of moving into a smaller firm size class. It decreases to 9.6 percent, but remains significant.

\section{---> Table 4 about here <---}

The determination of income works differently in wage-employment and self-employment. This is indicated by the significant interaction effects throughout the models. Furthermore, individual unobservable characteristics play an important role with respect to the size of the earnings difference. Finally, the switch into a smaller firm size class explains the earnings effect of self-employment only partly.

The earnings effect remains significant across industries. However, variations in size are observable: While a switch into self-employment within the construction industry is assiociated with an income difference of 7.3 percent, the effect within the finance and insurance industry reaches 10.8 percent. Within the services industry, a switch is connected with an earnings difference of 9.1 percent. A Hausman test is performed and its significant result reveals that a random-effects estimator would not be efficient. However, the application of a random-effects model leads to similar results as those of a fixed-effects model.

As described above, the earnings effect gained from a fixed-effects model indicates the average difference over time between the incomes in wage-employment and self-employment of a worker that moves from one sector to another. A first-differences estimator reveals the shortterm effect. The results are shown in Table 5. The sample size is smaller as the systematics of 
the estimator requires complete data for two subsequent years. With respect to the explaining variables, the model is equivalent to model (4) in Table 4. The short-term effect of selfemployment is already significant and has almost the same size as the average effect for a switch within the trade industry. A significant result for the finance and insurance industry with an effect of 9.5 percent can also be found. However, there are no significant coefficients with respect to the other industries. Generally, the estimated effects on earnings of the firstdifferences model are similar to those of the fixed-effects model.

First, this finding suggests that the positive financial impact of the switch into selfemployment can already be achieved in the short term. However, this is in contrast to the predictions of the investment models. It seems to be that the costs of investing in human capital are not as high as the short-term benefits. Second, the functionality described above of the fixed-effects estimator could lead to an underestimation of the income effect: Only workers with both spells in wage-employment and self-employment influence the effect. Hence, entrepreneurs who were already self-employed when they entered the GSOEP and who did not switch into wage-employment do not influence the effect at all. Yet, these entrepreneurs are supposed to manage well-established firms which should be more successful than firms that have been launched only recently. Their income is, indeed, higher: While the median income of workers who are continuously wage-employed is $2.578 €$, the median earnings of continuously self-employed workers is $4.046 €$. Workers that have both wage-employment and selfemployment spells in the GSOEP earn on average 3.011€. This is an indication that the size of the effect is somewhat underestimated respectively that the long-term effect is only insufficiently captured. 


\subsection{Robustness checks}

Challenging the results, one could argue that other contributions to this topic focus only on male workers as female workers often possess discontinued occupational careers (e.g. due to maternity leaves). As a consequence, the results could be biased. Restricting the data to male participants reveals similar coefficients for both the control variables and the $S E$ dummy. However, the restriction to female workers leads to an insignificant, but positive effect of selfemployment. Hence, it is straightforward that male workers benefit more from a switch into self-employment than female workers.

Furthermore, studies with regard to the German labor market often restrict their analyzes on West Germany. It is argued that the transformation process after the German reunification in 1990 of the East German workforce, that is, the adaption of a market economy, could bias the results. A regression equivalent to model (4) of Table 4 but based only on West Germans leads to an effect of self-employment of 15.0 percent. In contrast to this, the estimation for East German workers leads to a significant and negative effect of -14.8 percent. The effect is in particular strong directly after the German reunification and shrinks over time. This is an indication that there are indeed some adaption processes among the East German workers.

Similar to the considerations with respect to firm size, one could also argue that there is a variation of the weekly work time when switching into self-employment. Controlling for work time within the fixed-effects estimation leads to an income effect of self-employment given a constant number of work hours (precisely: the mean digit of the whole dataset). However, the descriptive statistics show that entrepreneurs work almost 10 hours more per week than employees. The main effect of work time indicates that a longer work time in wage-employment is correlated with more income. This holds true for self-employment. But due to the negative interaction effect, the total impact is smaller than in wage-employment. Model 2 in Table 6 
shows the results for an estimation of the monthly earnings without controlling for work time. That way, the effect of self-employment now also includes the fact that self-employed people work longer. Using this approach, the earnings difference rises up to 11.6 percent. This effect is also visible in the short term: A first-differences model which is identical with the model in Table 6, but does not control for the work time, reveals a significant income effect of 9.5 percent.

Other contributions gear to the hourly earnings instead to monthly income. As illustrated above, this seems to not be appropriate. However, the last model (3) reveals the result of a regression of the hourly income. Now, the effect of self-employment is not significant anymore. Altogether, one can conclude that the additional working hours that are connected with an entry into self-employment lead to a higher income on a monthly base, but have no effect on the hourly income.

---> Table 6 about here <---

Finally, German tax law differentiates between two forms of self-employed workers. On the one hand, there are the liberal professions as pharmacists, lawyers, or business consultants. Those require specific formal qualifications, like for example a certain university degree. Hence, those individuals should have been learnt specific knowledge and skills for their entrepreneurial job during their education. Furthermore, the job prior to their self-employment is supposed to have the character of a side job as their occupational aim is to get into a liberal profession. Hence, the measured income increase as a result of the switch from one job to another is bigger. About one quarter of all self-employed in the data is in a liberal profession. On the other hand, the remaining self-employed should be more heterogeneous with respect to 
their level of specifically entrepreneurial education. We can therefore expect that the impact on earnings should be higher for switches into liberal professions. The results support this assumption: When we compare switches from wage-employment into liberal professions with those into other entrepreneurial occupations by conducting separate regressions with corresponding dummy variables instead of the $S E$ dummy, we receive considerably higher effects in the trade ( 20.2 vs. 9.6 percent $)$ and the finance industry ( 17.9 vs. 6.6 percent). In the services industry, the coefficients for both kinds of self-employment are not significant. In the manufacturing area, the effect for liberal professions is not significant, but higher. Only in the construction industry, the results are inverted. In conclusion, workers benefit in particular when they switch into a liberal profession. However, entrepreneurial occupations in other fields are also connected with significantly higher earnings than in wage-employment.

\section{Summary and concluding remarks}

Using GSOEP data from 1984 to 2008, earnings differences between wage-employed and self-employed workers are analyzed. To allow for different earnings effects in both kind of jobs, all other determinants are interacted with the self-employment dummy. As the income is also influenced by other unobservable effects, a fixed-effects estimator is conducted which also captures some selection effects with respect to the entry into self-employment. In fact, the analysis shows that unobservable characteristics play an important role in determining earnings of self-employed people. Altogether, the results allow for the statement that there is clear evidence for a positive influence of self-employment on earnings in Germany. In some industries, this effect is already visible in the short run, that is, directly after the switch into self-employment. The effect on income is even bigger when taking into account that workers usually work longer when they are self-employed. 
There are some limitations which have to be kept in mind when we interpret the results. First, it is difficult to state which theoretical effect of those discussed in chapter 2 influences the results the most. Costs of investments in (human) capital that should emerge especially at the beginning of a business do not seem to be relevant as the income increases right after becoming self-employed. However, statements with respect to non-monetary rewards, to the role of self-employment income as a risk premium or to the impact of saved agency costs are not possible. Second, the GSOEP data includes possibly ambiguous self-employment earnings as they are self-reported by the entrepreneurs. This could foster problems in terms of a mixture of capital and labor earnings or due to different ways of saving for retirement. However, as there are also arguments for an underreporting of earnings by the self-employed, it is not straightforward if there is a systematic bias in the earnings variable. Third, results suggest that not all people benefit financially from a switch into self-employment: Workers in East Germany denote a significant decrease in their income. The switch into a liberal profession is connected with a higher income premium than in another entrepreneurial occupation. Men benefit more from self-employment than women. One possible explanation for these differences could be heterogeneous motivations for entrepreneurship. In the following, different motivations between women and men are discussed as an example.

On average, women do not benefit from the entry into an entrepreneurial occupation. Georgellis and Wall (2005) find that men are more responsive to income differences between a job in wage-employment and self-employment and they focus more on possible liquidity constraints when being an entrepreneur. Their results suggest that "women find selfemployment more desirable than do men because of its greater time-flexibility and other nonpecuniary aspects" (Georgellis and Wall, 2005), which is similar to the arguments illustrated in section 2. Furthermore, prior research showed that women are more often necessity entrepreneurs than men (see Bergmann and Sternberg (2007) and Wagner (2005) for descriptive 
results). The distinction of self-employed people in necessity and opportunity entrepreneurs has become quite popular. While the former indicate people that enter the self-employment sector due to the lack of other opportunities, the latter are people who instead move into selfemployment because of unique opportunities (Reynolds et al., 2001). The entrepreneurship literature suggests that these two groups benefit differently from becoming self-employed. It seems likely that the increase in earnings of opportunity entrepreneurs is larger than that of necessity entrepreneurs as they obtain significantly higher rewards (see Block and Wagner (2010) for a detailed analysis of income differences between those two groups). Unfortunately, the GSOEP data does not provide explicit information about this categorization of selfemployed workers. However, information about how the last job was terminated can be used. The answer categories of this variable, though, are ambiguous (for 2001, only 58.9 percent of job switchers can unambiguously be categorized, see Block and Wagner (2010)). In consequence, there are only few entrepreneurs with complete information which makes it difficult to identify significant effects compared to wage-employed workers. Therefore, it is a future task to differentiate the group of self-employed people with more appropriate data, especially with respect to different motivations for the switch from wage-employment to selfemployment.

Obviously, the results for Germany differ widely from those for the US. In the following, possible explanations will be discussed. The literature provides some evidence that the culture of self-employment in the US is different compared to Europe and especially to Germany as the barriers of becoming self-employed seem to be lower in the US. One possible barrier are opportunity costs: When German workers leave wage-employment, they also leave the rather extensive social security system of statutory pension insurance, unemployment insurance and health insurance in most cases. In contrast, social security benefits are considerably lower in the US. Another barrier could be social and cultural norms which encourage people to start a 
new business and increase their personal wealth. In the 2010 Report of the Global Entrepreneurship Monitor (GEM), experts were asked about the most positive and most negative factors influencing the national degree of entrepreneurship in different countries. While these norms are seen as one of the most positive factors in the US, they are one of most negative in Germany (Kelley et al., 2011). In addition to these external factors, there is also evidence that US and German workers differ with respect to their subjective perceptions. Köllinger et al. (2007) find that considerably more US workers see themselves capable of setting up an own company, while German workers face a higher fear of failure when they ponder the idea of establishing their own firm. The authors can show that these differences in subjective perceptions explain huge parts of country-specific differences in the probability of being both a nascent entrepreneur or an established entrepreneur.

The existence of these barriers leads to the conclusion that there should be more entrepreneurs in the US. Grilo and Thurik (2005) and Gohmann (2010) show that the rate of latent entrepreneurship is considerably higher in the US. Latent entrepreneurs are workers that prefer being self-employed compared to being an employee. The effect is also significant when controlling for other factors influencing the probability of preferring self-employment like sociodemographic characteristics or the individual risk tolerance. The results for actual entrepreneurship are comparable: In the US, more workers are self-employed (Gohmann, 2010). Consequently, German workers who get over the described barriers and switch into selfemployment should be more successful in an entrepreneurial occupation as their US counterparts. They are willing to take the risk of failure only if they are rather sure about the success in terms of monetary rewards, for instance. The results of Grilo and Thurik (2008) deliver some indications for this assumption. They find that the probability of having an own earlystage business (less than three years old) instead of never having thought about self- 
employment is higher in the US than in Germany. However, the opposite is true for businesses that are well-established (more than three years old).

In conclusion, entrepreneurial income compared to earnings from wage-employment should remain in focus. Future empirical research should investigate more profoundly the revealed international differences, preferably by means of a joint dataset of US and European respectively German workers. 


\section{References}

Astebro, T., Thompson, P., 2009. Entrepreneurs: Jacks of All Trades or Hobos?, Discussion $\begin{array}{llllll}\text { Paper } & \text { (downloaded } & \text { on } & 071 & \text { December } & \text { from }\end{array}$ http://papers.ssrn.com/sol3/papers.cfm?abstract_id=925221).

Becker, G.S., 1962. Investment in Human Capital: A Theoretical Analysis. Journal of Political Economy 70, 9-49.

Benz, M., Frey, B.S., 2008. Being Independent is a Great Thing: Subjective Evaluations of Self-Employment and Hierarchy. Economica 75, 362-383.

Bergmann, H., Sternberg, R., 2007. The Changing Face of Entrepreneurship in Germany. Small Business Economics 28, 205-221.

Block, J., Köllinger, P., 2009. I Can't Get No Satisfaction - Necessity Entrepreneurship and Procedural Utility. Kyklos 62, 191-209.

Block, J., Sandner, P., Wagner, M., Weiglein, M., 2009. Unternehmensgründungen von Ausländern in Deutschland: Einkommenseffekte und Implikationen für die Gründungslehre, SOEPpaper No. 196 (downloaded on 07 December 2011 from http://www.diw.de/documents/publikationen/73/diw_01.c.99430.de/diw_sp0196.pdf).

Block, J.H., Wagner, M., 2010. Necessity and Opportunity Entrepreneurs in Germany: Characteristics and Earnings Differentials. Schmalenbach Business Review 62, 154-174.

Caliendo, M., Fossen, F.M., Kritikos, A.S., 2011. Personality Characteristics and the Decision to Become and Stay Self-Employed, IZA Discussion Paper No. 5566 (downloaded on 07 December 2011 from http://ftp.iza.org/dp5566.pdf).

Cameron, A.C., Trivedi, P.K., 2009. Microeconometrics using Stata, College Station, Texas.

Douhan, R., van Praag, M., 2009. Entrepreneurship, Wage Employment and Control in an Occupational Choice Framework, IZA Discussion Paper No. 4211 (downloaded on 07 December 2011 from http://ftp.iza.org/dp4211.pdf).

Georgellis, Y., Wall, H., 2005. Gender Differences in Self-Employment. International Review of Applied Economics 19, 321-342. 
Gohmann, S.F., 2010. Institutions, Latent Entrepreneurship, and Self-Employment: An International Comparison. Entrepreneurship Theory and Practice.

Grilo, I., Thurik, R., 2005. Latent and Actual Entrepreneurship in Europe and the US: Some Recent Developments. International Entrepreneurship and Management Journal 1, 441-459.

Grilo, I., Thurik, R., 2008. Determinants of Entrepreneurial Engagement Levels in Europe and the US. Industrial and Corporate Change 17, 1113-1145.

Hamilton, B.H., 2000. Does Entrepreneurship Pay? An Empirical Analysis of the Returns to Self-Employment. Journal of Political Economy 108, 604-631.

Hammarstedt, M., 2009. Predicted Earnings and the Propensity for Self-Employment. International Journal of Manpower 30, 349-359.

Hartog, J., Van Praag, M., Van Der Sluis, J., 2010. If You Are So Smart, Why Aren't You an Entrepreneur? Returns to Cognitive and Social Ability: Entrepreneurs Versus Employees. Journal of Economics \& Management Strategy 19, 947-989.

Jensen, S.T., Shore, S.H., 2008. Changes in the Distribution of Income Volatility, Discussion Paper (downloaded on 07 December 2011 from http://arxiv.org/pdf/0808.1090).

Johansson, E., 2000. Self-Employment and the Predicted Earnings Differential - Evidence from Finland. Finnish Economic Papers 13, 45-55.

Kawaguchi, D., 2002. Compensating Wage Differentials among Self-Employed Workers: Evidence from Job Satisfaction Scores, ISER Discussion Paper No. 568. Institute of Social and Economic Research, Osaka University (downloaded on 07 December 2011 from http://www.iser.osaka-u.ac.jp/library/dp/2002/DP0568.PDF).

Kelley, D.J., Bosma, N., Amorós, J.E., 2011. Global Entrepreneurship Monitor: 2010 Global Report (downloaded on $07 \quad$ December 2011 from http://www.gemconsortium.org/download/1323267749858/GEM\%20GLOBAL\%20REPORT \%202010rev.pdf).

Köllinger, P., Minniti, M., Schade, C., 2007. "I think I can, I think I can": Overconfidence and Entrepreneurial Behavior. journal of economic psychology 28, 502-527.

Lazear, E.P., 1981. Agency, Earnings Profiles, Productivity, and Hours Restrictions. American Economic Review 71, 606-620. 
Lazear, E.P., 2005. Entrepreneurship. Journal of Labor Economics 23, 649-680.

Lazear, E.P., Moore, R.L., 1984. Incentives, Production, and Labor Contracts. Quarterly Journal of Economics 99, 275-296.

Lohmann, H., Luber, S., 2004. Trends in Self-Employment in Germany: Different Types, Different Developments?, in: Arum, R., Müller, W. (Eds.), The Reemergence of SelfEmployment Princeton University Press, Princeton, New Jersey, pp. 36-74.

OECD, 1992. Employment Outlook. OECD Publications, Paris (online downloaded on 07 December 2011 from http://www.oecd.org/dataoecd/58/39/2485491.pdf).

Parker, S.C., 2004. The Economics of Self-Employment and Entrepreneurship, Cambridge.

Reynolds, P.D., Camp, S.M., Bygrave, W.D., Autio, E., Hay, M., 2001. Global Entrepreneurship Monitor 2001 Executive Report. Babson College and London Business School, Babson Park/London.

van Praag, M., van Witteloostuijn, A., van der Sluis, J., 2009. Returns for Entrepreneurs vs. Employees: The Effect of Education and Personal Control on the Relative Performance of Entrepreneurs vs. Wage Employees, IZA Discussion Paper No. 4628 (downloaded on 07 December 2011 from http://ftp.iza.org/dp4628.pdf).

van Praag, M., Versloot, P.H., 2008. The Economic Benefits and Costs of Entrepreneurship: A Review of the Research, Boston, Delft.

Wagner, J., 2005. Der Noth gehorchend, nicht dem eignen Trieb Nascent Necessity and Opportunity Entrepreneurs in Germany Evidence from the Regional Entrepreneurship Monitor (REM). University of Lüneburg, Working Paper Series in Economics (downloaded $\begin{array}{llll}\text { on } & 07 & \text { December from }\end{array}$ http://www.leuphana.de/fileadmin/user_upload/Forschungseinrichtungen/ifvwl/WorkingPaper s/wp_10_Upload.pdf).

Williams, D.R., 2003. Returns to Education and Experience in Self-Employment: Evidence for Germany. Schmollers Jahrbuch 123, 139-150.

Wooldridge, J.M., 2006. Introductory econometrics. Thomson, Mason, Ohio. 
Tables and Figures

Table 1: Descriptive statistics

\begin{tabular}{|c|c|c|c|c|}
\hline & & $\begin{array}{l}\text { SE workers } \\
\mathrm{N}=\mathbf{1 0 , 3 8 1}\end{array}$ & $\begin{array}{l}\text { WE workers } \\
\mathrm{N}=124,949\end{array}$ & $\underset{N=\mathbf{1 3 5 , 3 3 0}}{\text { All }}$ \\
\hline $\begin{array}{l}\text { Sex } \\
\text { Female } \\
\text { Male }\end{array}$ & & $\begin{array}{l}0.239 \\
0.761\end{array}$ & $\begin{array}{l}0.329 \\
0.671\end{array}$ & $\begin{array}{l}0.322 \\
0.678\end{array}$ \\
\hline $\begin{array}{l}\text { Nationality } \\
\text { German } \\
\text { Foreigner }\end{array}$ & & $\begin{array}{l}0.913 \\
0.087\end{array}$ & $\begin{array}{l}0.839 \\
0.161\end{array}$ & $\begin{array}{l}0.845 \\
0.155\end{array}$ \\
\hline $\begin{array}{l}\text { Marital Status } \\
\text { Non married } \\
\text { Married }\end{array}$ & & $\begin{array}{l}0.266 \\
0.734\end{array}$ & $\begin{array}{l}0.334 \\
0.666\end{array}$ & $\begin{array}{l}0.329 \\
0.671\end{array}$ \\
\hline $\begin{array}{l}\text { Children in household } \\
\text { No children } \\
\text { At least } 1 \text { child }\end{array}$ & & $\begin{array}{l}0.576 \\
0.424\end{array}$ & $\begin{array}{l}0.609 \\
0.391\end{array}$ & $\begin{array}{l}0.606 \\
0.394\end{array}$ \\
\hline Age [years] & $\begin{array}{l}\text { Mean } \\
\text { SD }\end{array}$ & $\begin{array}{l}44.4 \\
10.5\end{array}$ & $\begin{array}{l}40.0 \\
10.9\end{array}$ & $\begin{array}{l}40.4 \\
11.0\end{array}$ \\
\hline Schooling [years] & $\begin{array}{l}\text { Mean } \\
\text { SD }\end{array}$ & $\begin{array}{c}13.0 \\
2.9\end{array}$ & $\begin{array}{c}11.9 \\
2.7\end{array}$ & $\begin{array}{c}12.0 \\
2.7\end{array}$ \\
\hline $\begin{array}{l}\text { Unemployment experience } \\
\text { [months] }\end{array}$ & $\begin{array}{l}\text { Mean } \\
\text { SD }\end{array}$ & $\begin{array}{l}0.36 \\
1.06\end{array}$ & $\begin{array}{l}0.35 \\
1.04\end{array}$ & $\begin{array}{l}0.35 \\
1.05\end{array}$ \\
\hline $\begin{array}{l}\text { In occupation trained for } \\
\text { Yes } \\
\text { No }\end{array}$ & & $\begin{array}{l}0.630 \\
0.370\end{array}$ & $\begin{array}{l}0.572 \\
0.428\end{array}$ & $\begin{array}{l}0.576 \\
0.424\end{array}$ \\
\hline $\begin{array}{l}\text { In public sector } \\
\text { Yes } \\
\text { No }\end{array}$ & & $\begin{array}{l}0.015 \\
0.985\end{array}$ & $\begin{array}{l}0.271 \\
0.729\end{array}$ & $\begin{array}{l}0.251 \\
0.749\end{array}$ \\
\hline $\begin{array}{l}\text { Firm size } \\
\text { Self-employed without employees } \\
\text { Up to } 20 \text { employees } \\
\text { Up to } 200 \text { employees } \\
\text { Up to } 2,000 \text { employees } \\
\text { Over } 2,000 \text { employees }\end{array}$ & & $\begin{array}{l}0.298 \\
0.624 \\
0.044 \\
0.011 \\
0.022\end{array}$ & $\begin{array}{l}0.001 \\
0.185 \\
0.295 \\
0.255 \\
0.265\end{array}$ & $\begin{array}{l}0.024 \\
0.219 \\
0.276 \\
0.236 \\
0.246\end{array}$ \\
\hline Tenure [years] & $\begin{array}{l}\text { Mean } \\
\text { SD }\end{array}$ & $\begin{array}{l}10.2 \\
10.0\end{array}$ & $\begin{array}{c}11.0 \\
9.8\end{array}$ & $\begin{array}{c}11.0 \\
9.8\end{array}$ \\
\hline Weekly working time [hours] & $\begin{array}{l}\text { Mean } \\
\text { SD }\end{array}$ & $\begin{array}{l}52.1 \\
13.7\end{array}$ & $\begin{array}{c}42.7 \\
7.3\end{array}$ & $\begin{array}{c}43.4 \\
8.3\end{array}$ \\
\hline $\begin{array}{l}\text { Industry } \\
\text { Manufacturing } \\
\text { Construction } \\
\text { Trade } \\
\text { Finance } \\
\text { Services }\end{array}$ & & $\begin{array}{l}0.158 \\
0.152 \\
0.299 \\
0.220 \\
0.171\end{array}$ & $\begin{array}{l}0.380 \\
0.088 \\
0.174 \\
0.093 \\
0.265\end{array}$ & $\begin{array}{l}0.363 \\
0.093 \\
0.184 \\
0.102 \\
0.257\end{array}$ \\
\hline
\end{tabular}

Notes: Tabulated are fractions. 
Table 2: Self-employment status and earnings

\begin{tabular}{|c|c|c|c|c|}
\hline & & $\begin{array}{l}\text { SE workers } \\
(\mathrm{n}=\mathbf{1 0 , 3 8 1})\end{array}$ & $\begin{array}{l}\text { WE workers } \\
(\mathrm{n}=\mathbf{1 2 4 , 9 4 9 )}\end{array}$ & $\begin{array}{c}\text { All workers } \\
(\mathbf{n}=\mathbf{1 3 5 , 3 3 0})\end{array}$ \\
\hline $\begin{array}{l}\text { Monthly earnings }{ }^{1} \\
\text { [euro] }\end{array}$ & $\begin{array}{l}\text { Mean } \\
\text { SD } \\
10 \% \\
25 \% \\
50 \% \\
75 \% \\
90 \%\end{array}$ & $\begin{array}{l}3,828 \\
3,113 \\
\\
1,176 \\
1,919 \\
3,027 \\
4,796 \\
7,232\end{array}$ & $\begin{array}{l}2,689 \\
1,332 \\
\\
1,432 \\
1,877 \\
2,420 \\
3,181 \\
4,207\end{array}$ & $\begin{array}{l}2,777 \\
1,572 \\
\\
1,411 \\
1,877 \\
2,446 \\
3,253 \\
4,411\end{array}$ \\
\hline $\begin{array}{l}\text { Hourly earnings }{ }^{1} \\
\text { [Euro] }\end{array}$ & $\begin{array}{l}\text { Mean } \\
\text { SD } \\
10 \% \\
25 \% \\
50 \% \\
75 \% \\
90 \%\end{array}$ & $\begin{array}{c}18.58 \\
18.62 \\
\\
5.41 \\
8.52 \\
13.84 \\
22.56 \\
35.22\end{array}$ & $\begin{array}{c}15.09 \\
12.53 \\
\\
7.72 \\
10.31 \\
13.45 \\
17.49 \\
22.77\end{array}$ & $\begin{array}{c}15.36 \\
13.13 \\
\\
7.54 \\
10.20 \\
13.47 \\
17.73 \\
23.49\end{array}$ \\
\hline
\end{tabular}

${ }^{1}$ In prices of 2008 
Figure 1: Monthly earnings over time 1984-2008

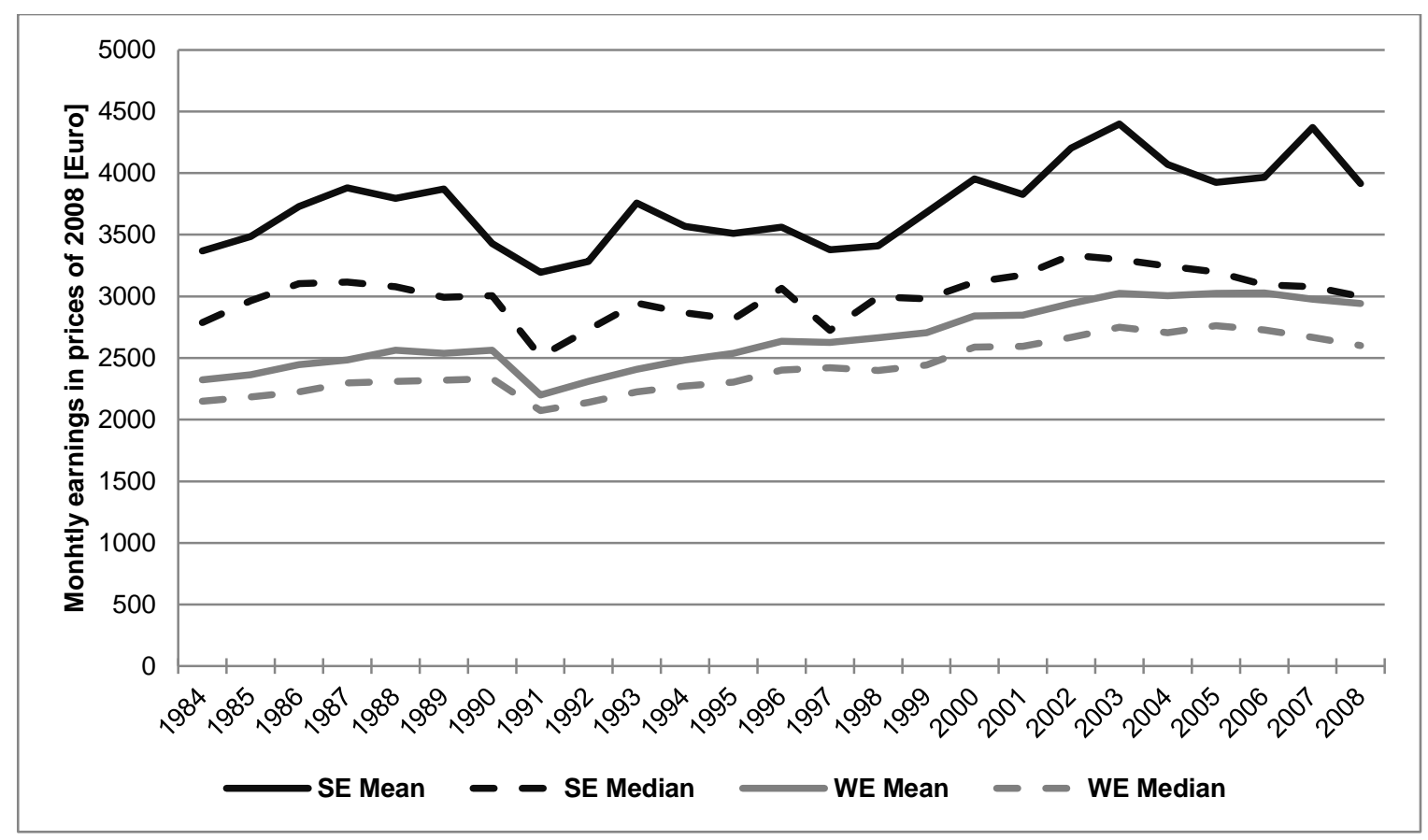

Figure 2: Hourly earnings over time 1984-2008

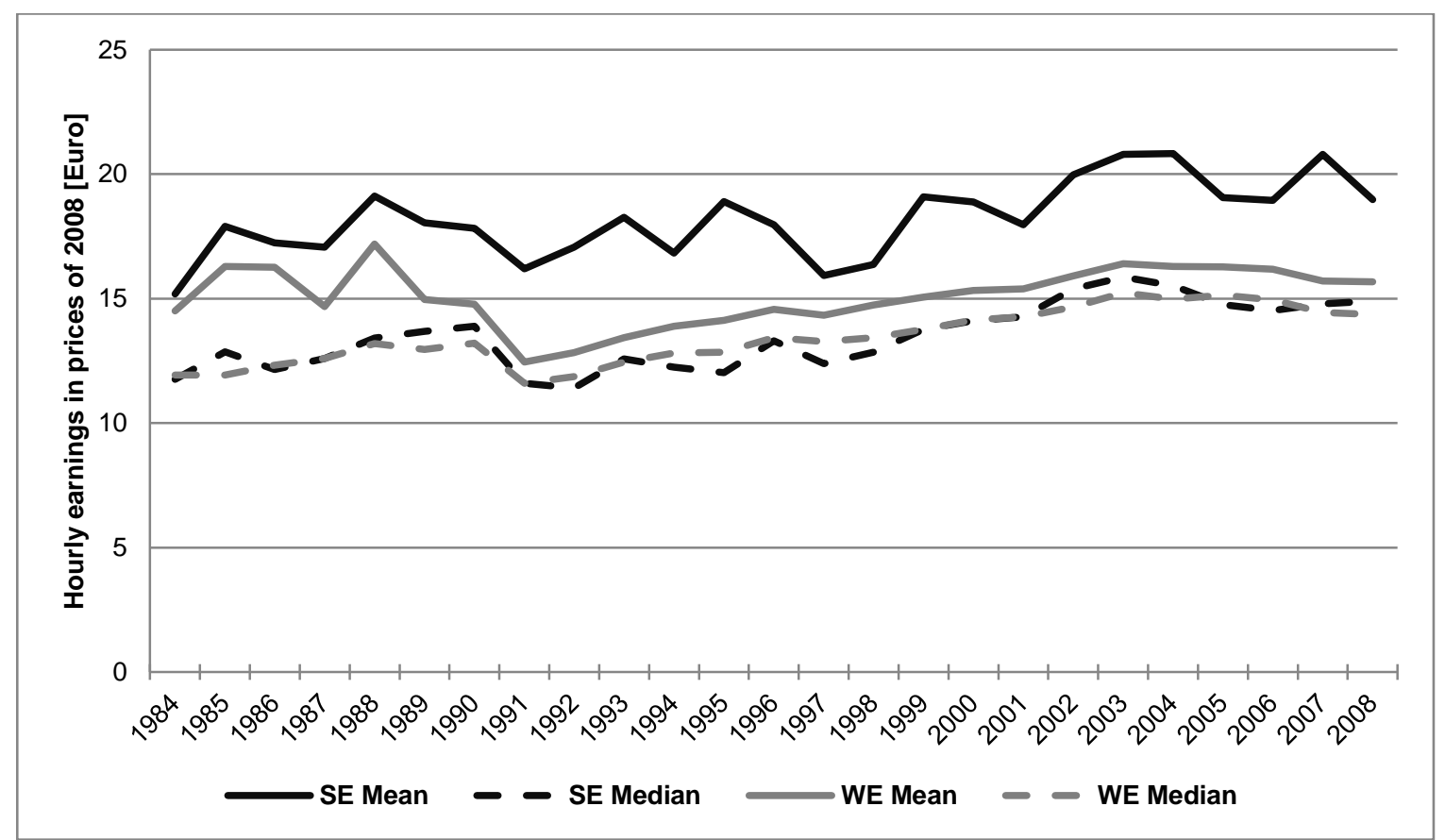


Table 3: Self-employment status and earnings increases

\begin{tabular}{|c|c|c|c|c|c|}
\hline & & $\begin{array}{c}\text { No switch WE } \\
\text { t-1=WE, } t=W E \\
(n=97,641)\end{array}$ & $\begin{array}{c}\text { Switch } S E \rightarrow W E \\
\text { t-1=SE, } t=W E \\
(n=498)\end{array}$ & $\begin{array}{c}\text { Switch } W E \rightarrow S E \\
\text { t-1=WE, } \rightarrow=S E \\
(n=685)\end{array}$ & $\begin{array}{c}\text { No switch SE } \\
\text { t-1=SE, } t=S E \\
(n=6,885)\end{array}$ \\
\hline \multirow{7}{*}{$\begin{array}{l}\text { Increase in } \\
\text { monthly earnings } 1 \\
\text { [percentage] }\end{array}$} & Mean & +0.051 & +0.145 & +0.334 & +0.144 \\
\hline & $10 \%$ & -0137 & 0505 & 0370 & 0307 \\
\hline & $25 \%$ & -0.036 & -0.292 & -0.126 & -0.180 \\
\hline & $50 \%$ & +0.013 & -0.021 & +0.087 & -0.010 \\
\hline & $75 \%$ & +0.096 & +0.205 & +0.472 & +0.246 \\
\hline & $90 \%$ & +0.242 & +0.630 & +1.075 & +0.664 \\
\hline & $\begin{array}{l}\text { Fraction } \\
\text { Winners }^{2}\end{array}$ of & 0.551 & 0.426 & 0.591 & 0.474 \\
\hline \multirow{7}{*}{$\begin{array}{l}\text { Increase in } \\
\text { hourly earnings }{ }^{1} \\
\text { [percentage] }\end{array}$} & Mean & +0.087 & +0.304 & +0.344 & +0.262 \\
\hline & $10 \%$ & -0.175 & -0.549 & -0.462 & -0.445 \\
\hline & $25 \%$ & -0.062 & -0.258 & -0.239 & -0.205 \\
\hline & $50 \%$ & +0.018 & +0.005 & -0.006 & +0.009 \\
\hline & $75 \%$ & +0.122 & +0.346 & +0.424 & +0.313 \\
\hline & $90 \%$ & +0.290 & +0.912 & +1.095 & +0.878 \\
\hline & $\begin{array}{l}\text { Fraction of } \\
\text { Winners }^{2}\end{array}$ & 0.563 & 0.506 & 0.493 & 0.511 \\
\hline
\end{tabular}

${ }^{1}$ In prices of 2008

2"Winners" are workers who denote a positive increase in earnings from period t-1 to period $\mathrm{t}$. 
Table 4: Multivariate estimations

\begin{tabular}{|c|c|c|c|c|}
\hline & \multicolumn{4}{|c|}{ dependent variable: $\log$ (monthly earnings in euro of prices of 2008) } \\
\hline & $\begin{array}{l}\text { OLS } \\
(1)\end{array}$ & $\begin{array}{l}\text { Fixed-effects } \\
\text { (2) }\end{array}$ & $\begin{array}{l}\text { Fixed-effects } \\
\text { (3) }\end{array}$ & $\begin{array}{l}\text { Fixed-effects } \\
\text { (4) }\end{array}$ \\
\hline Self-employed (SE) & $0.1718 * * *(0.0080)$ & $0.1029 * * *(0.0158)$ & $0.1221 * * *(0.0391)$ & $0.0917 * *(0.0384)$ \\
\hline $\begin{array}{l}\text { Female } \\
\text { SE x Female }\end{array}$ & $-0.1986 * * *(0.0023)$ & & $-0.0154(0.0353)$ & $-0.0133(0.0361)$ \\
\hline $\begin{array}{l}\text { Foreigner } \\
\text { SE x Foreigner }\end{array}$ & $-0.0291 * * *(0.0028)$ & $0.0430 * * *(0.0166)$ & $\begin{array}{c}0.0320 *(0.0171) \\
0.1789 * * *(0.0432)\end{array}$ & $\begin{array}{c}0.0298 *(0.0172) \\
0.1792 * * *(0.0428)\end{array}$ \\
\hline $\begin{array}{l}\text { Married } \\
\text { SE x Married }\end{array}$ & $0.0236 * * *(0.0024)$ & $0.0248 * * *(0.0046)$ & $\begin{array}{l}0.0247 * * *(0.0044) \\
-0.0038(0.0236)\end{array}$ & $\begin{array}{l}0.0256 * * *(0.0045) \\
-0.0033(0.0236)\end{array}$ \\
\hline $\begin{array}{l}\text { Children in household } \\
\text { SE x Children }\end{array}$ & $0.0254 * * *(0.0023)$ & $-0.0057 *(0.0034)$ & $\begin{array}{c}-0.0058 *(0.0033) \\
0.0041(0.0182)\end{array}$ & $\begin{array}{l}-0.0061 *(0.0033) \\
0.0079(0.0184)\end{array}$ \\
\hline $\begin{array}{l}\text { Age }- \text { mean }(\text { age }) \\
\text { SE } x[\text { Age }- \text { mean }(\text { age })] \\
(\text { Age }- \text { mean }(\text { age }))^{2 *} 100 \\
\text { SE } x\left[(\text { Age }- \text { mean }(\text { age }))^{2}\right] * 100\end{array}$ & $\begin{array}{l}0.0063 * * *(0.0001) \\
-0.0352 * * *(0.0010)\end{array}$ & $\begin{array}{l}0.0195 * * *(0.0005) \\
-0.0449 * * *(0.0019)\end{array}$ & $\begin{array}{c}0.0198 * * *(0.0005) \\
-0.0052 * * *(0.0018) \\
-0.0427 * * *(0.0018) \\
0.0001(0.0092)\end{array}$ & $\begin{array}{c}0.0197 * * *(0.0005) \\
-0.0057 * * *(0.0018) \\
-0.0433 * * *(0.0018) \\
0.0005(0.0093)\end{array}$ \\
\hline $\begin{array}{l}\text { Schooling - mean(schooling) } \\
\text { SE x [Schooling - mean(schooling)] }\end{array}$ & $0.0537 * * *(0.0005)$ & $0.0134 * * *(0.0026)$ & $\begin{array}{l}0.0136 * * *(0.0026) \\
-0.0066(0.0056)\end{array}$ & $\begin{array}{l}0.0136 * * *(0.0026) \\
-0.0062(0.0057)\end{array}$ \\
\hline $\begin{array}{l}\text { Unemp. exp. - mean(unemp. exp.) } \\
\text { SE x [Unemp. exp. - mean(unemp. exp.)] }\end{array}$ & $-0.0306^{* * *}(0.0010)$ & $-0.0607 * * *(0.0049)$ & $\begin{array}{c}-0.0603 * * *(0.0048) \\
-0.0074(0.0128)\end{array}$ & $\begin{array}{l}-0.0607 * * *(0.0048) \\
-0.0093(0.0134)\end{array}$ \\
\hline $\begin{array}{l}\text { In occupation trained for } \\
\text { SE x In occupation trained for }\end{array}$ & $0.0729 * * *(0.0022)$ & $0.0144 * * *(0.0036)$ & $\begin{array}{l}0.0145 * * *(0.0034) \\
-0.0021(0.0210)\end{array}$ & $\begin{array}{c}0.0128 * * *(0.0034) \\
0.0044(0.0210)\end{array}$ \\
\hline $\begin{array}{l}\text { In public sector } \\
\text { SE x In public sector }\end{array}$ & $-0.0245^{* * *}(0.0031)$ & $-0.0189 * * *(0.0057)$ & $\begin{array}{c}-0.0198 * * *(0.0056) \\
0.0150(0.0461)\end{array}$ & $\begin{array}{c}-0.0135 * *(0.0056) \\
0.0221(0.0464)\end{array}$ \\
\hline $\begin{array}{l}\text { Tenure }- \text { mean }(\text { tenure }) \\
\text { SE x }[\text { Tenure }- \text { mean }(\text { tenure })] \\
(\text { Tenure }- \text { mean }(\text { tenure }))^{2} * 100 \\
\text { SE x }\left[(\text { Tenure }- \text { mean }(\text { tenure }))^{2}\right]^{*} 100\end{array}$ & $\begin{array}{l}0.0060 * * *(0.0002) \\
-0.0154 * * *(0.0011)\end{array}$ & $\begin{array}{l}0.0012 * * *(0.0004) \\
-0.0122 * * *(0.0019)\end{array}$ & $\begin{array}{c}0.0011 * * *(0.0004) \\
0.0021(0.0018) \\
-0.0125 * * *(0.0018) \\
-0.0136(0.0094) \\
\end{array}$ & $\begin{array}{c}0.0013 * * *(0.0004) \\
0.0037 * *(0.0019) \\
-0.0130 * * *(0.0018) \\
-0.0161 *(0.0094)\end{array}$ \\
\hline $\begin{array}{l}\text { Working time }- \text { mean(working time) } \\
\text { SE x [Working time }- \text { mean(working time)] }\end{array}$ & $0.0086 * * *(0.0002)$ & $0.0041 * * *(0.0002)$ & $\begin{array}{l}0.0043 * * *(0.0002) \\
-0.0012 * *(0.0006)\end{array}$ & $\begin{array}{l}0.0042 * * *(0.0002) \\
-0.0010 *(0.0006)\end{array}$ \\
\hline $\begin{array}{l}\text { Industry } \\
\text { Manufacturing } \\
\text { Construction } \\
\text { Trade } \\
\text { Finance } \\
\text { Services } \\
\text { SE x Manufacturing } \\
\text { SE x Construction } \\
\text { SE x Trade } \\
\text { SE x Finance } \\
\text { SE x Services }\end{array}$ & $\begin{array}{c}0.1012 * * *(0.0030) \\
0.1105 * * *(0.0040) \\
--- \text { reference }--- \\
0.1770 * * *(0.0044) \\
0.0746 * * *(0.0037)\end{array}$ & $\begin{array}{c}0.0334 * * *(0.0058) \\
0.0542 * * *(0.0083) \\
--- \text { reference }--- \\
0.0298 * * *(0.0089) \\
-0.0069(0.0080)\end{array}$ & $\begin{array}{c}0.0413 * * *(0.0057) \\
0.0571 * * *(0.0082) \\
--- \text { reference }--- \\
0.0287 * * *(0.0086) \\
-0.0036(0.0078) \\
\\
-0.0064(0.0274) \\
-0.0221(0.0319) \\
--- \text { reference --- } \\
0.0116(0.0313) \\
-0.0045(0.0350)\end{array}$ & $\begin{array}{c}0.0360 * * *(0.0056) \\
0.0590 * * *(0.0081) \\
--- \text { reference --- } \\
0.0276 * * *(0.0085) \\
-0.0066(0.0077) \\
\\
-0.0075(0.0273) \\
-0.0253(0.0315) \\
--- \text { reference --- } \\
0.0256(0.0313) \\
0.0034(0.0348)\end{array}$ \\
\hline $\begin{array}{l}\text { Firm Size } \\
\text { Self-employed without employees } \\
\text { Up to } 20 \text { employees } \\
\text { Up to } 200 \text { employees } \\
\text { Up to } 2,000 \text { employees } \\
\text { Over } 2,000 \text { employees } \\
\text { SE x self-employed without employees } \\
\text { SE x Up to } 20 \text { employees } \\
\text { SE x Up to } 200 \text { employees } \\
\text { SE x Up to } 2,000 \text { employees } \\
\text { SE x Over } 2,000 \text { employees }\end{array}$ & $\begin{array}{l}-0.1541 * * *(0.0142) \\
--- \text { reference }--- \\
0.1166 * * *(0.0030) \\
0.1717 * * *(0.0031) \\
0.2146 * * *(0.0032)\end{array}$ & $\begin{array}{l}-0.0692 * * *(0.0167) \\
--- \text { reference }--- \\
0.0375 * * *(0.0047) \\
0.0490 * * *(0.0056) \\
0.0620 * * *(0.0061)\end{array}$ & $\begin{array}{c}-0.0712(0.0759) \\
--- \text { reference --- } \\
0.0351 * * *(0.0047) \\
0.0487 * * *(0.0055) \\
0.0632 * * *(0.0060) \\
0.0018(0.0772) \\
--- \text { reference }--- \\
0.1173 * * *(0.0374) \\
-0.0212(0.0600) \\
-0.1209 * * *(0.0433)\end{array}$ & \\
\hline Intercept & $7.5880 * * *(0.0070)$ & $7.8014 * * *(0.0220)$ & $7.8014 * * *(0.0219)$ & $7.8390^{* * *}(0.0214)$ \\
\hline $\begin{array}{l}\text { Overall } \\
\text { Within } \\
\text { Between }\end{array}$ & 0.4800 & $\begin{array}{l}0.2310 \\
0.2081 \\
0.2470\end{array}$ & $\begin{array}{l}0.2275 \\
0.2046 \\
0.2446\end{array}$ & $\begin{array}{l}0.2164 \\
0.2044 \\
0.2321\end{array}$ \\
\hline Observations (Persons) & 135,330 & & $135,330(20,793)$ & \\
\hline
\end{tabular}


Table 5: First-differences estimation

\begin{tabular}{|c|c|}
\hline & dependent variable: $\log ($ monthly earnings in euro of prices of 2008) \\
\hline Self-employed (SE) & $0.0913 * *(0.0447)$ \\
\hline SE $x$ female & $-0.0456(0.0416)$ \\
\hline $\begin{array}{l}\text { Foreigner } \\
\text { SE x Foreigner }\end{array}$ & $\begin{array}{c}0.0024(0.0172) \\
0.1328 * * *(0.0499)\end{array}$ \\
\hline $\begin{array}{l}\text { Married } \\
\text { SE x Married }\end{array}$ & $\begin{array}{c}0.0092 * *(0.0044) \\
0.0302(0.0294)\end{array}$ \\
\hline $\begin{array}{l}\text { Children in household } \\
\text { SE x Children }\end{array}$ & $\begin{array}{c}-0.0085^{* *}(0.0036) \\
0.0182(0.0249)\end{array}$ \\
\hline $\begin{array}{l}\text { Age }- \text { mean }(\text { age }) \\
\text { SE x }[\text { Age }- \text { mean }(\text { age })] \\
(\text { Age }- \text { mean }(\text { age }))^{2 * 100} \\
\text { SE x }\left[(\text { Age }- \text { mean }(\text { age }))^{2}\right]^{*} 100\end{array}$ & $\begin{array}{c}0.0289 * * *(0.0007) \\
-0.0050 * *(0.0022) \\
-0.0697 * * *(0.0032) \\
0.0092(0.0140) \\
\end{array}$ \\
\hline $\begin{array}{l}\text { Schooling - mean(schooling) } \\
\text { SE x [Schooling - mean(schooling)] }\end{array}$ & $\begin{array}{l}0.0101 * * *(0.0028) \\
-0.0084(0.0059)\end{array}$ \\
\hline $\begin{array}{l}\text { Unemp. exp. - mean(unemp. exp.) } \\
\text { SE x [Unemp. exp. - mean(unemp. exp.)] }\end{array}$ & $\begin{array}{c}-0.0641^{* *}(0.0320) \\
0.0035(0.0175)\end{array}$ \\
\hline $\begin{array}{l}\text { In occupation trained for } \\
\text { SE } x \text { In occupation trained for }\end{array}$ & $\begin{array}{r}0.0006(0.0032) \\
-0.0191(0.0224)\end{array}$ \\
\hline $\begin{array}{l}\text { In public sector } \\
\text { SE x In public sector }\end{array}$ & $\begin{array}{l}-0.0047(0.0052) \\
0.0658(0.0616)\end{array}$ \\
\hline $\begin{array}{l}\text { Tenure }- \text { mean (tenure) } \\
\text { SE x }[\text { Tenure }- \text { mean }(\text { tenure })] \\
(\text { Tenure }- \text { mean }(\text { tenure }))^{2} \\
\text { SE x }\left[(\text { Tenure }- \text { mean }(\text { tenure }))^{2}\right]\end{array}$ & $\begin{array}{c}-0.0022 * * *(0.0006) \\
0.0040 *(0.0023) \\
0.0003(0.0037) \\
-0.0095(0.0149) \\
\end{array}$ \\
\hline $\begin{array}{l}\text { Working time }- \text { mean (working time) } \\
\text { SE x [Working time }- \text { mean(working time)] }\end{array}$ & $\begin{array}{l}0.0021 * * *(0.0001) \\
-0.0006(0.0005)\end{array}$ \\
\hline $\begin{array}{l}\text { Industry } \\
\text { Manufacturing } \\
\text { Construction } \\
\text { Trade } \\
\text { Finance } \\
\text { Services }\end{array}$ & $\begin{array}{c}0.0176 * * *(0.0056) \\
0.0047(0.0085) \\
--- \text { reference }--- \\
0.0158 * *(0.0076) \\
-0.0182 * *(0.0079)\end{array}$ \\
\hline $\begin{array}{l}\text { SE x Manufacturing } \\
\text { SE x Construction } \\
\text { SE x Trade } \\
\text { SE x Finance } \\
\text { SE x Services }\end{array}$ & $\begin{array}{l}-0.0306(0.0291) \\
-0.0228(0.0336) \\
--- \text { reference }--- \\
0.0001(0.0332) \\
-0.0101(0.0381)\end{array}$ \\
\hline $\mathrm{R}^{2}$ & 0.0202 \\
\hline Observations & 105,753 \\
\hline
\end{tabular}

Notes: Clustered standard errors in parentheses. Also controlled for region and year of observation. 
Table 6: Earnings and working time

\begin{tabular}{|c|c|c|c|c|}
\hline & & \multicolumn{3}{|c|}{ Fixed effects, dependent variable: $\log$ (earnings in euro of prices of 2008) } \\
\hline & & $\begin{array}{l}\text { Monthly earnings } \\
\text { (1) }\end{array}$ & $\begin{array}{l}\text { Monthly earnings } \\
\text { (2) }\end{array}$ & $\begin{array}{l}\text { Hourly earnings } \\
\text { (3) }\end{array}$ \\
\hline \multicolumn{2}{|c|}{ Self-employed (SE) } & $0.0917 * *(0.0384)$ & $0.1096^{* * *}(0.0379)$ & $-0.0351(0.0406)$ \\
\hline \multicolumn{2}{|c|}{$\begin{array}{l}\text { Working time - mean(working time) } \\
\text { SE x [Working time }- \text { mean(working time)] }\end{array}$} & $\begin{array}{l}0.0042 * * *(0.0002) \\
-0.0010 *(0.0006)\end{array}$ & & \\
\hline $\mathrm{R}^{2}$ & $\begin{array}{l}\text { Overall } \\
\text { Within } \\
\text { Between }\end{array}$ & $\begin{array}{l}0.2164 \\
0.2044 \\
0.2321\end{array}$ & $\begin{array}{l}0.2013 \\
0.1952 \\
0.2147\end{array}$ & $\begin{array}{l}0.1740 \\
0.1140 \\
0.2117\end{array}$ \\
\hline \multicolumn{2}{|c|}{ Observations (Persons) } & \multicolumn{3}{|c|}{$135,330(20,793)$} \\
\hline
\end{tabular}

Notes: Robust standard errors in parentheses. The models are in all other respects identical to model (4) of Table 4. 


\section{Appendix: Variable definitions and operationalization}

\begin{tabular}{|c|c|}
\hline Variable & Description \\
\hline Self-Employed & Dummy for a self-employed worker \\
\hline Monthly Earnings & Monthly Earnings in Euro of prices in 2008 \\
\hline Female & Dummy for a female worker \\
\hline Foreigner & Dummy for a worker who is not German by nationality \\
\hline Children in household & $\begin{array}{l}\text { Dummy for a worker with at least one child under the age of } 16 \text { in } \\
\text { her/his household }\end{array}$ \\
\hline Age & Current age of the worker (in years) \\
\hline Years of schooling & $\begin{array}{l}\text { Years of education at school and university }(7=\text { no schooling de- } \\
\text { gree, } 18=\text { university degree })\end{array}$ \\
\hline Unemployment experience & Cumulated months of unemployment during the whole working life \\
\hline In occupation trained for & $\begin{array}{l}\text { Dummy for a worker whose occupation is the same in which she/he } \\
\text { was trained }\end{array}$ \\
\hline In public sector & Dummy for a worker whose occupation is in the public sector \\
\hline Firm size & $\begin{array}{l}\text { Dummies for the size of the actual firm in which the worker is } \\
\text { occupied. As a proxy, the number of employees of the firm is used. } \\
\text { There are four different categories: (1) Up to } 19 \text { employees, (2) } 20 \\
\text { to } 199 \text { employees, (3) } 200 \text { to } 1,999 \text { employees and (4) at least } \\
2,000 \text { employees }\end{array}$ \\
\hline Tenure & Tenure with the actual firm (in years) \\
\hline Weekly working time & Actual working time per week (in hours) \\
\hline Industry & 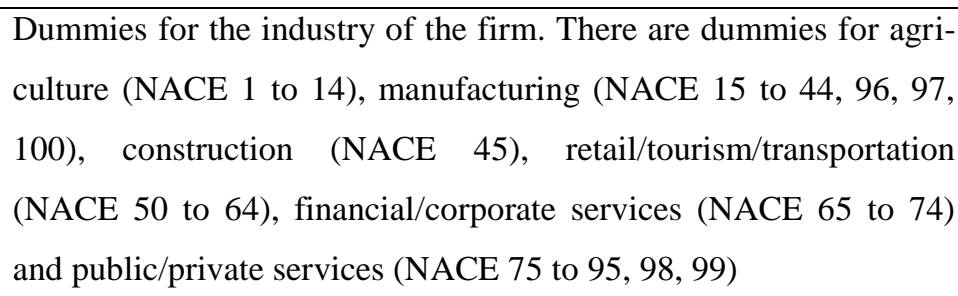 \\
\hline Year of observations & Dummies for the years of observation \\
\hline
\end{tabular}

